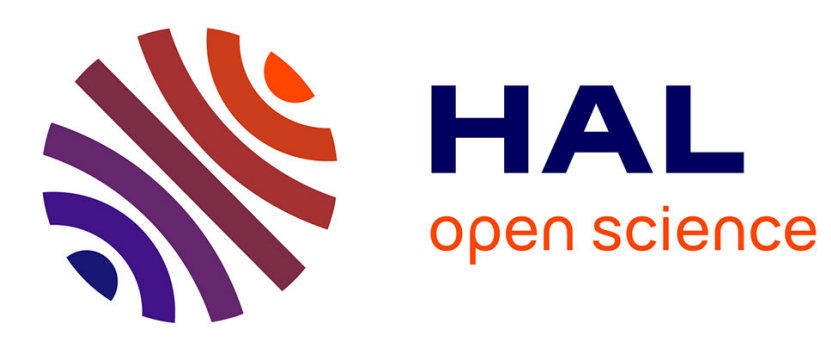

\title{
The social representations of the Bali climate conference in the French and German media
}

\author{
Sabine Caillaud, Nikos Kalampalikis, Uwe Flick
}

\section{To cite this version:}

Sabine Caillaud, Nikos Kalampalikis, Uwe Flick. The social representations of the Bali climate conference in the French and German media. Journal of Community and Applied Social Psychology, 2011, 22 (4). halshs- 01206398

\section{HAL Id: halshs-01206398 \\ https://shs.hal.science/halshs-01206398}

Submitted on 10 Jul 2017

HAL is a multi-disciplinary open access archive for the deposit and dissemination of scientific research documents, whether they are published or not. The documents may come from teaching and research institutions in France or abroad, or from public or private research centers.
L'archive ouverte pluridisciplinaire HAL, est destinée au dépôt et à la diffusion de documents scientifiques de niveau recherche, publiés ou non, émanant des établissements d'enseignement et de recherche français ou étrangers, des laboratoires publics ou privés. 


\section{ResearchGate}

See discussions, stats, and author profiles for this publication at:

http://www.researchgate.net/publication/227719535

\section{The Social Representations of the Bali Climate Conference in the French and German Media}

ARTICLE in JOURNAL OF COMMUNITY \& APPLIED SOCIAL PSYCHOLOGY · JULY 2012 Impact Factor: 1.19 - DOI: 10.1002/casp.1117

3 AUTHORS, INCLUDING:

\section{Sabine Caillaud}

Université René Descartes - Par...

11 PUBLICATIONS 13 CITATIONS

SEE PROFILE

\section{Nikos Kalampalikis}

Université Lumiere Lyon 2

71 PUBLICATIONS 216 CITATIONS

SEE PROFILE 
Journal of Community \& Applied Social Psychology

J. Community Appl. Soc. Psychol., 22: 363-378 (2012)

Published online 25 August 2011 in Wiley Online Library

(wileyonlinelibrary.com) DOI: 10.1002/casp.1117

\title{
The Social Representations of the Bali Climate Conference in the French and German Media
}

\author{
S. CAILLAUD ${ }^{1 *}$, N. KALAMPALIKIS ${ }^{2}$ and U. FLICK ${ }^{3}$ \\ ${ }^{1}$ Laboratoire de psychologie des menaces sociales et environnementales (EA 4471), University Paris Descartes, France \\ ${ }^{2}$ Research Group in Social Psychology (EA 4163), University of Lyon, Lyon, France \\ ${ }^{3}$ Alice Salomon Fachhochschule, Berlin, Germany and University of Vienna, Austria
}

\begin{abstract}
Climate change is a major current affair for which recent United Nations climate conferences aim to build consensus and develop international solutions. The objective of this article is to compare, through the theoretical lens of social representations, the way in which French and German media, specifically newspapers, represent the Bali climate conference. We use the triangulation of data analysis to take both the pragmatic and the semantic aspects of media discourse into account. Results show that German media adopt both a local and a global vision of climate change and of the conference. Religious metaphors highlight a moral dimension of the conference, suggesting anchoring in human and political categories. In contrast, in French media, we identify that conflicts between countries render the stakes of climate change concrete by war metaphors. The French discourses examined are shown to be organised through the anchoring of political and financial categories. Results are discussed in relation to the history of green movements in the two countries and in relation to practical implications. Copyright (C) 2011 John Wiley \& Sons, Ltd.
\end{abstract}

Key words: climate change; climate conference; social representations; France; Germany; media; triangulation

\section{INTRODUCTION}

Climate change is often presented as one of the major environmental problems of our era. Various countries within the United Nations (UN) have gathered annually since 1990 to build consensus and develop solutions. The Kyoto protocol of 1997 undoubtedly marks a turning point because the signatory countries committed to reduce their level of greenhouse gases by 5.2\%. The objective of the UN Bali Conference in 2007 was to organise the subsequent step to the Kyoto protocol. These conferences constitute moments of 'crisis' in environmental negotiations, bringing the 'taken for granted' to

*Correspondence to: Caillaud, Sabine, Laboratoire de psychologie des menaces sociales et environnementales, Université Paris Descartes, 71 Avenue Edouard Vaillant, 92774 Boulogne Billancourt.

E-mail: sabine.caillaud@parisdescartes.fr 
the forefront in media in which meanings are contested and controversial representations proposed (Foster, 2006). This article focuses on the results of qualitative and quantitative analysis carried out on daily newspaper articles that covered the Bali conference published in France and Germany. The aim is to compare the way media in both countries represent climate change and the UN conference to find out if there is consensus. How do media discourses report on this conference in both countries? Which SRs are communicated? Which objectification and anchoring categories are used?

\section{A comparison between France and Germany}

France and Germany were selected for this study because they share a certain number of similarities: both are modern European industrial and capitalist democracies with comparable populations and economic structures. However, they also show important differences, notably regarding their interpretation of environmental issues. As a point of departure for our comparison, we therefore turn to their respective ideological and political interpretations of the environment.

Since the 1960s, environmental organisations have flourished in both France and West Germany (in East Germany, such organisations were State controlled until 1989). In Germany, organisations that defend local interests (Bürgerinitiativen) were grouped together around a common and federating ideological discourse (Jacquiot, 2007) centred on ethical reflections (Chibret, 1991). In France, by contrast, environmental organisations were drawn together by the May 1968 movement of political dissent. The green movement in France however is divided as some consider that environmental debates should remain outside all political arenas and actions should be science based only (Chibret, 1991). This difference in the destiny of environmental organisations in France and Germany can be explained in various ways. Certain hypotheses (which propose that Germany marked by its Nazi past seeks to reduce its level of guilt) have been rejected for more sociological explanations (Jacquiot, 2008). Other theories lean towards a more ancient heritage, such as the philosophical current of the Age of Enlightenment in France and the Romantics of Germany. Both still strongly influence each country's specific relationship to nature (Ferry, 1992). Recourse to scientific knowledge as the only reference in many of the French organisations (Ollitrault, 2001) can indeed be understood to echo the tradition dating back to the Age of Enlightenment.

Those different philosophical currents left traces such as can be observed in French-style gardens or the wild public gardens in Germany. These elements of the past are also likely to be the object of multiple uses in the present (Haas \& Jodelet, 1999). Therefore, Eder (2000) considered that environmental issues could constitute a federating objective for post-war Germany and probably have integrated certain elements from its past, notably from the Romantic era. Nevertheless, more recent studies show that quantitative differences persist between French and German attitudes and environmental behaviours (see Eurobarometer, $2002,{ }^{1} 2004^{2}$ ). Sociological studies have also highlighted important differences, both in eco-counselors (Rudolf, 1998) and in the heart of public discourse on certain environmental questions such as waste (Keller, 1998).

\footnotetext{
${ }^{1}$ http://ec.europa.eu/environment/pubs/pdf/brochure_fr.pdf (accessed 13 July 2010).

${ }^{2}$ http://ec.europa.eu/environment/archives/barometer/pdf/summary_ebenv_2005_04_22_fr.pdf (accessed 13 July 2010).
} 
These very differences lead us to investigate how their leading daily newspapers treat climate change and environmental conferences in two after all quite similar countries. We seek to understand how the debates are presented and if a consensus exists between both countries.

\section{THEORETICAL BACKGROUND}

In general, SRs can be defined as 'a set of beliefs, images, metaphors and symbols collectively shared in a group, community, society or culture' (Wagner, 1994, p. 199). Two major processes intervene in the construction of SR: objectification and anchoring. The central idea in the anchoring process is to integrate new phenomena-objects, experiences, relations, practices and so forth-into existing worldviews and categories (Flick, 1995). More specifically, anchoring 'serves to weave parental relations between the newly issued significances of the social sphere, and the reservoir of already existing knowledge that is culturally available and accessible. [...]Metaphorically speaking, anchoring quenches the thirst for familiarisation with the un-familiar' (Kalampalikis \& Haas, 2008, p. 453/454). The objectification process involves 'information selection' and its 'schematisation' that in turn allows for 'naturalisation' to occur in which representational constructs are projected as concrete entities in the lifeworld (Jodelet, 2008, p.425). Images or metaphors are linked to the new phenomena, and the abstract becomes concrete. Objectification and anchoring work in tandem and are complementary to one another (Joffe, 2003; Marková, 2003).

The social representation (SR) approach offers specific advantages for studying a group's relationship to the environment. Considered more than a place in which we live, it is the object of SRs, related both to identity dynamics (Bonaiuto, Breakwell \& Cano, 1996) and to a given social and historical context (Gervais, 1997). Moreover, the SR approach provides a framework with which one can make sense of certain paradoxes observed in lay knowledge (Castro \& Lima, 2001). This approach is particularly pertinent for the canvas of our study because SR are socially constructed, shared on a local and global level, and can take into account this double aspect of local and global environmental problems (Castro, 2006). In other words, with an SR approach, we can study the global phenomena and local consequences of climate change which themselves inspire change in individual practices.

\section{GRASPING SRS THROUGH MEDIA ANALYSIS}

Since the early developments of the SR approach, the role of communication and language has been considered central (Wagner, 1998; Marková, 2000; Moscovici, 2001). In terms of the SR of the environment, mass communication holds a particularly important place. Individuals are often aware of environmental problems only through media and are not directly confronted with global problems such as climate change (Hansen, 1991). For example, research on how French and German study participants describe the first time they remember having encountered an environmental problem points out that, half of the time, they describe events they only experienced indirectly such as those reported on by media or even by a close friend referencing media discourse (Caillaud, 2009). Media therefore provide an access to certain environmental problems which otherwise 
remain imperceptible. Even if the content of media is not necessarily equivalent to that of the thoughts of individuals (Joffe \& Haarhoff, 2002), their role in the formation and transformation of SR is not negligible. For example, Bauer (2005) showed how the dichotomy red/green that structures media discourse around genetically modified organisms (GMOs) reappears not only in the discourse of those who read the press but also in the discourse of nonreaders, illustrating the importance of media discourse.

However, if media recreate and transmit SR, their discourse is also manufactured and modelled by the sociocultural context in which this discourse and the SR themselves are constructed. The notion of 'cultural resonance' highlights the fact that certain events echo a specific cultural context (Gamson \& Modigliani, 1989). For example, the Chernobyl accident was presented in the US American press as an event related to the dynamics of the Cold War. So, 'understanding media roles in the construction of the environment and environmental issues as social problems ....... becomes a question of mapping the dynamic and interactive elaboration of issues as they are articulated, often in parallel, in different forms of meaning creation' (Hansen, 1991, p. 449). Media thus appear as a space in which SR are both reconstructed and reflected and therefore their analysis becomes relevant.

\section{METHODOLOGY}

\section{Data collection}

We conducted a broad study in France and Germany about the SRs of ecological problems and practices on the basis of a qualitative research design, which included media analysis. Our comparison of the SR reconstructed by media in both countries is drawn from our analysis of the way in which the press reports on a single event: the UN climate conference held in Bali from 3 to 16 December 2007.

To carry out this study, we turned to national general daily papers, which constitute 'opinion leaders' (Bauer, 2005). We selected the four most widely read daily papers in France and Germany, carefully excluding financial and sports focused newspapers. For the samples to be comparable, we excluded the Bild Zeitung, a sensationalist German newspaper exclusively sold in kiosks and for which there is no French equivalent. Table 1 shows the different newspapers selected in addition to the number of examples printed.

Table 1. Newspapers retained and number of examples printed

\begin{tabular}{lllr}
\hline \multicolumn{1}{c}{ France } & \multicolumn{2}{c}{ Germany } \\
\hline Newspaper title & $\begin{array}{c}\text { Number } \\
\text { printed }\end{array}$ & \multicolumn{1}{c}{ Newspaper title } & $\begin{array}{c}\text { Number } \\
\text { printed }\end{array}$ \\
\hline $\begin{array}{l}\text { Aujourd'hui en France } \\
\text { (le Parisien) (AF) }\end{array}$ & 506,200 & Süddeutsche Zeitung (SZ) & $1,150,000$ \\
$\begin{array}{l}\text { Le Monde (LM) } \\
\text { Le Figaro (LF) }\end{array}$ & 397,400 & Frankfurter Allgemeine Zeitung (FAZ) & 900,000 \\
Libération (Li) & 353,600 & Die Welt (DW) & 590,000 \\
\hline
\end{tabular}

Source for French media figures: «The 2004 Media Observatory » (observatoire des médias chiffres 2004). Source for German media figures: «2004 Media Perspective» (Media Perspektiven. Basisdaten 2004). 
After preliminary reading, we defined the following keywords to access articles from the database (Factiva):

- For the French newspapers: «(negociation* or sommet or conference) and climat* and Bali ${ }^{3} .^{3}$

- For the German newspapers: «(weltklimagipfel or klimagipfel or weltklimakonferenz or klimakonferenz) and Bali ». ${ }^{4}$

For one of the German newspapers, the Frankfurter Allgemeine Zeitung (FAZ), we had to choose the articles directly from a CD-ROM because it was not indexed by Factiva nor any other database.

Data were selected from a window of time that takes the entire period of the conference into account, adding the days following the conference to compare the traces it could leave shortly afterwards. The period of data collection therefore extends from Monday, 3 December 2007 (the opening day of the conference), to Monday, 24 December 2007 ( 1 week after the end of the conference). Some articles did not focus on the conference and were excluded from analysis (Foster, 2006).

\section{Data analysis}

We carried out double analysis of our data on the model of triangulation (Flick, 1992) in which each method refers to a specific theoretical perspective about discourse. We conducted pragmatic analysis (Moscovici, 1994) using the Alceste method (Kalampalikis \& Moscovici, 2005). We also added a more qualitative analysis by identifying the different metaphors used by the press, pointing towards the semantic aspects of discourse.

Figure 1 represents the adopted triangulation perspective, used to complement the results as strategy for quality and for validating results (Flick, 1992). This methodological design refers to the fact that SR are constructed and shared at the pragmatic and semantic levels, both of which need to be taken into account (Moscovici, 1994).

\section{Pragmatic analysis of the corpus with the Alceste method}

'Alceste' (signifying 'Analyses of Co-occurring Lexemes in the Simple Enunciations of a Text') is a method of statistical lexical analysis frequently used in SRs research (cf. e.g. Lahlou, 1996, 2001; Licata \& Klein, 2002, Kalampalikis, 2003). The corpus is divided into small fragments of text units (according to the number of analysed words and punctuation), called elementary contextual units (ECUs). Then, the ECUs and their lexical profiles are crossed to form a contingency table that shows the distribution of the vocabulary. From this contingency table, a square distance matrix is generated: two ECUs are close to each other if they share some analysed words. Classes are then constructed on purely statistical criteria (word co-occurrence and redundancy in text units). The method identifies the statistically significant vocabulary characterising each class for further analysis and interpretation. Each class should then be interpreted in relation to the others (Kalampalikis, 2003). Thus, the Alceste method, by investigating the distribution of vocabulary and by applying

\footnotetext{
${ }^{3}$ English translation for the French newspapers: «(negotiation* or summit meeting or conference) and climate* and Bali».

${ }^{4}$ English translation for the German newspapers: «(international climate summit meeting or climate summit meeting or international climate conference or climate conference) and Bali ».
} 


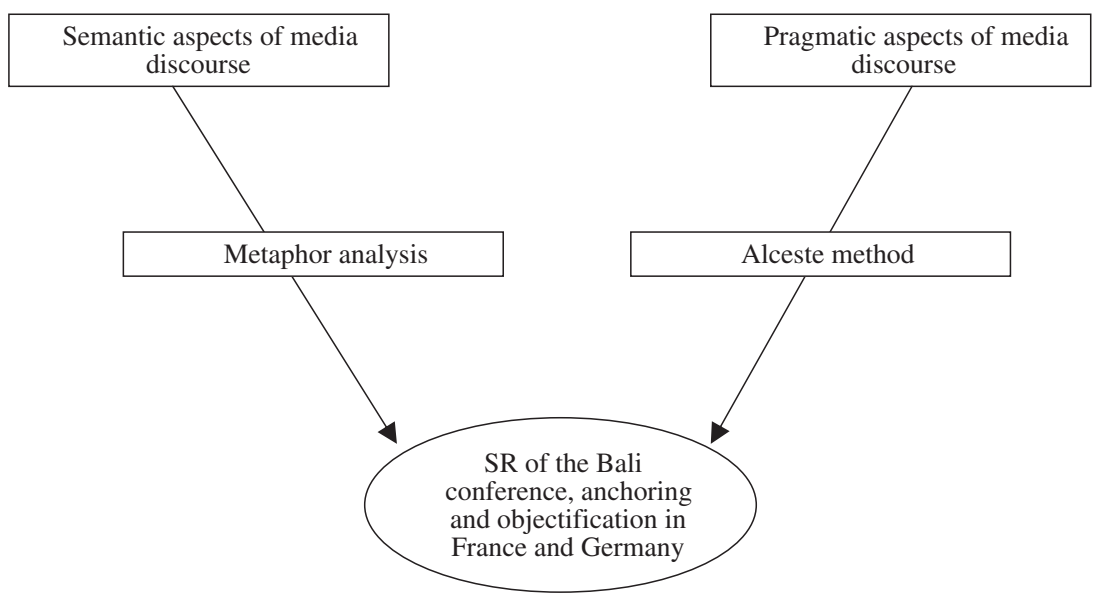

Figure 1. Triangulation perspective.

statistical methods to identify repetitive language patterns, can be used as a pragmatic analysis of discourse (Kalampalikis \& Moscovici, 2005).

The analysis takes into account a certain number of external variables which for our study included the newspaper in which the article was published, the date of publication and the column in which it was published. This method allowed us to find out if certain lexical classes were specific to a newspaper during the defined period of the conference.

According to Kronberger and Wagner (2003, p. 307), 'the assumption of Alceste is that different points of reference produce different ways of talking, that is, the use of a specific vocabulary is seen as a source for detecting ways of thinking about an object'. In this way, lexical classes, by referring to a way of talking and thinking about the object, can be potentially interpreted as reference spaces and anchoring categories. In addition, specific attention given to the words themselves can inform us about the process of objectification (as images used, concrete examples, etc.).

\section{The use of metaphors in the semantic analysis of the corpus}

Metaphor can be considered 'a device to make something less familiar more familiar' that 'impregnates the target with characteristics which originally pertain to the source' (Wagner, Elejabarrieta \& Lahnsteiner, 1995, p. 675). Also, metaphors can lead to a process of objectification and are additionally informative on the anchoring process. For example, as Castro and Gomes (2005) showed in the case of a biotechnology study, if the metaphors used are AIDS or sores, illness is one category of anchoring. Metaphors therefore lead us directly to the process of objectification, and we can trace back to the anchoring categories. However, in order for a metaphor to induce a process of objectification, certain criteria need to be respected, as is highlighted by Wagner et al. (1995). To identify the metaphors, we compare the basic contemporary meaning of each lexical unity to the meaning in context (Pragglejaz, 2007). If the signification varies, we then note it as a metaphor. In Lakoff's terminology, this basic contemporary meaning echoes the source domain (Wagner et al., 1995). We only studied the lexical units of nouns, adjectives and verbs. 
Also, one way of examining the semantic aspects of discourse is the study of metaphors which implies looking closely into the word's meaning.

\section{RESULTS}

Results based on the number of newspaper articles on the subject evidence that German media report more (164 articles) on the conference than French media (86 articles) $\left(\chi^{2}=24.3\right.$, significant at. 001). However, articles are not longer in one country than the other $(t=0.83)$. Moreover, our results show that this quantitative difference is significant only for the first week of the conference. There were no more major differences after the ministers from all countries had arrived in Bali (the second and last week). Finally, French media published most of the articles in the scientific columns of the reviewed newspapers whereas German articles were mostly published in political columns $\left(\chi^{2}=112.65\right.$, significant at. 001).

\section{Alceste analysis: a description of the pragmatic aspects}

To begin, we will describe the different lexical worlds for each of the two corpuses which inform us about the way both countries represent the conference. We will then proceed to our comparison from which some conclusions will be drawn.

\section{Lexical worlds identified in Germany}

The German corpus was divided into four classes of words, shown in Figure 2. Classes 1 and 2 are the lexical worlds that relate more specifically to the conference in contrast to classes 3 and 4, which are more focused on climate change and its consequences.

Class 4 corresponds to a little more than half of the corpus, pointing to its importance as a way of talking about the conference. Similarly, class 1 represents more than a quarter of the corpus from which we can identify that the classes are thus very different in quantitative terms. Also, the different ways of thinking about the conference exist

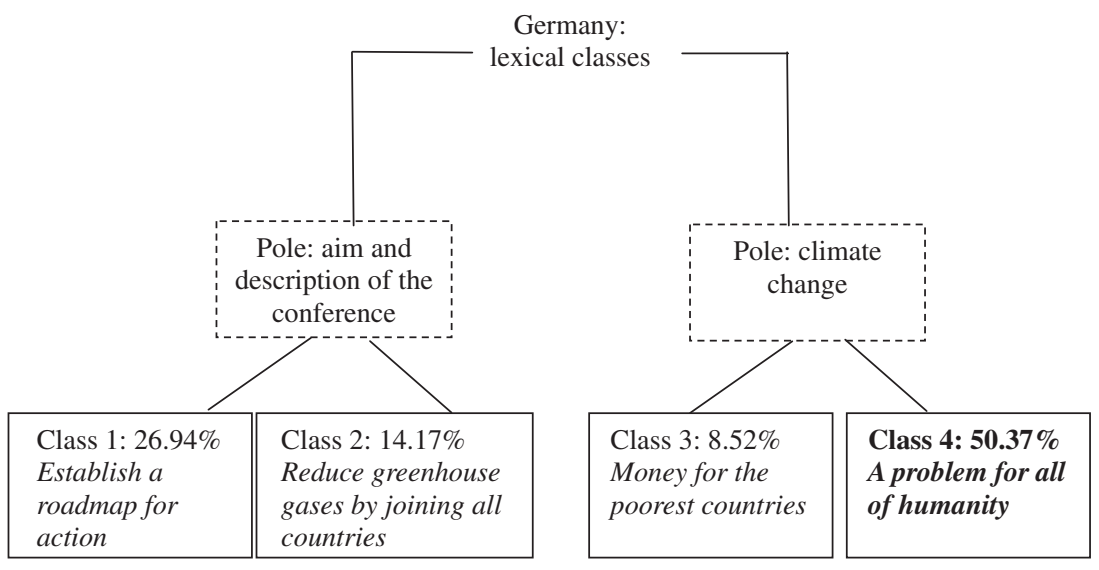

Figure 2. Outline of lexical classes for German data. 
but they are quantitatively unequal. Table 2 gives the most representative words for each class and additionally indicates the relevant variables.

Class 1 of the corpus points to the general theme of the conference dynamics, such as editing timetables and roadmaps for action, and to an important role occupied by the German Minister of Environment. Words such as $\mathrm{CO}_{2}$, energy or climate change are absent, but verbs are numerous, reflecting a local description of the political debates in which the USA appears as one of the principal negotiators: 'At the beginning of the Bali conference's crucial phase, the USA and the European Union quarreled' (Süddeutsche Zeitung [SZ], 13/12, our translation). In contrast, class 2 does not accentuate discussions related to the conference but instead emphasises the geopolitical stakes of greenhouse gases and the capacity of each country to reduce their greenhouse gases: 'The EU proposed a 30\% reduction compared to 1990, if other industrial countries would commit, including an agreement from China and India' (FAZ, 3/12). Here, the focus is not on a political agenda or actions to be taken but rather on a more global perspective that directly addresses greenhouse gas reduction. This class was notably important at the beginning of the conference during which numerous countries were cited as well as the rate of their greenhouse gases.

The difference between class 2 (the beginning of the conference) and class 1 (the middle of the conference) concerns the manner in which conference dynamics are mentioned. If in the beginning of the conference the German press raises the global aim for all countries to

Table 2. Word classes (Alceste) for the German corpus

\begin{tabular}{|c|c|c|}
\hline Title & Most representative words & Significant variables \\
\hline $\begin{array}{l}\text { Class 1: establish a roadmap } \\
\text { for action }\end{array}$ & $\begin{array}{l}\text { Negotiations, Bali, Gabriel, De Boer, week, } \\
\text { accords, action plan, Kyoto, finish, } \\
\text { mandate, contract, clear, conference, USA, } \\
\text { Copenhagen, Bush, Saturday, new, } \\
\text { protocol, to begin, night, newspaper, } \\
\text { Friday, environmental minister }\end{array}$ & $\begin{array}{l}\text { Ministers' arrival } \\
\text { period; section: } \\
\text { first page }\end{array}$ \\
\hline $\begin{array}{l}\text { Class 2: reduce greenhouse } \\
\text { gases through international } \\
\text { agreements }\end{array}$ & $\begin{array}{l}\text { Percentage, programme, China, industrial } \\
\text { countries, India, to correct, homework, } \\
\text { lower, obliged, developing countries, } \\
\text { reduce, level, Greenhouse gases, to emit, } \\
\text { Europe, protocol, reduce by half, to accept, } \\
\text { Kyoto, Brazil, to fill up, presidency, to } \\
\text { promise, long term }\end{array}$ & $\begin{array}{l}\text { Beginning of the } \\
\text { conference }\end{array}$ \\
\hline $\begin{array}{l}\text { Class } 3 \text { : money for the } \\
\text { poorest countries }\end{array}$ & $\begin{array}{l}\text { Dollar, billion, funds, adaptation, millions, } \\
\text { to help, to evaluate, annual, to suffer, to } \\
\text { finance, adaptation funds, disforestation, } \\
\text { volume, the poorest, developing countries, } \\
\text { to follow, World Bank, money, Euros, } \\
\text { technology, climate change, study, project, } \\
\text { forest }\end{array}$ & $\begin{array}{l}\text { From the beginning } \\
\text { to the middle of } \\
\text { the conference }\end{array}$ \\
\hline $\begin{array}{l}\text { Class } 4 \text { : a problem for all } \\
\text { of humanity }\end{array}$ & $\begin{array}{l}\text { Humans, each, a lot, to give, institute, } \\
\text { weeks, as, to know, power, international, } \\
\text { where, earth, to do, entire, something, } \\
\text { NGO, again, Man, to catch, to be, long, } \\
\text { humanity, biofuel, elongated, blocked, } \\
\text { researcher, energy, politics }\end{array}$ & $\begin{array}{l}\text { Throughout the } \\
\text { conference }\end{array}$ \\
\hline
\end{tabular}


reduce greenhouse gases, little by little this discourse changes towards a description of conference dynamics from a local perspective (such as roadmaps for action, etc.).

In class 3, numerous words refer to money (e.g. dollar, billion, funds, million, finance), and it is exclusively in this class that we find words referring to change (e.g. adaptation funds, transfer of technology), to deforestation, and the presence of verbs such as to help or to support. In terms of countries that are cited in this class, we identify the words the rich and the poor. However, the terms debate or negotiation are significantly absent. This class brings up the notion of aid to poorer countries, a theme that does not, however, appear to foster debate. Indeed, words such as suffer, risk and save can also be found in this class, revealing the human stakes at risk with greenhouse gases.

Class 4 is by far the most important class of the German corpus (50.37\%), with specific vocabulary such as human, humanity, everyone, Earth and protect. Here, more than elsewhere, we find possessive determinants, leading to a description of a global problem that concerns everyone: 'All around the world, more and more humans are worried about the consequences of climate change' (Die Welt [DW], 3/12). However, an even more precise vocabulary, biospirit, energy, car and air conditioner, appears to indicate that a relationship is drawn between a global problem and its more local and daily aspects.

Classes 3 and 4 are thus distinct in that the prior describes local problems relevant to poor countries whereas the latter describes problems related to all of humanity and presents climate change as a more global reality. In this context, the discussion about poor countries adaptation appears as a single example separate from the problem for humanity as a whole. Nonetheless, it is interesting to note that the question of poor countries is not asked in the same terms. As for classes 1 and 2, a relationship between local and global apprehension was found for classes 3 and 4.

\section{Lexical worlds identified in France}

Figure 3 represents the different lexical worlds obtained from the Alceste software for the French corpus. Classes 1 and 2 relate more specifically to financial stakes, whereas class 3 is focused on political stakes. Three classes were identified (see table 3 for more details).

Class 3 takes on particular importance in this corpus $(55.83 \%)$ because of the presence of a large number of terms related to temporality (months and days) and proper nouns.

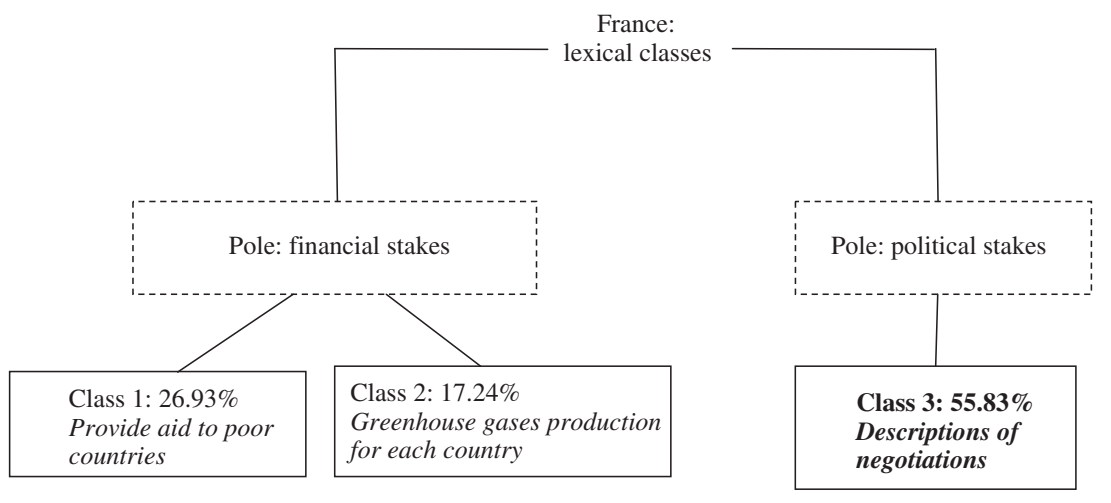

Figure 3. Outline of lexical classes for French data. 
Table 3. Word classes (Alceste) for the French corpus

\begin{tabular}{|c|c|c|}
\hline Title & Most representatives words & Significant variables \\
\hline $\begin{array}{l}\text { Class } 1 \text { : provide aid to } \\
\text { poor countries }\end{array}$ & $\begin{array}{l}\text { Dollar, billion, development, project, } \\
\text { transfer, technology, deforestation, } \\
\text { Euros, adaptive, financial, clean, help, } \\
\text { bank, funds, forest, million, south, clean } \\
\text { development mechanisms, Africa }\end{array}$ & $\begin{array}{l}\text { From December } 10 \\
\text { to } 12\end{array}$ \\
\hline $\begin{array}{l}\text { Class 2: greenhouse gases } \\
\text { production for each country } \\
\text { and financial stakes }\end{array}$ & $\begin{array}{l}\text { Emissions, gas, China, reduce, greenhouse, } \\
\text { rights, India, effect, level, emerging, sector, } \\
\text { to approach, to put, to pollute, rival, } \\
\text { consumption, reduction, permanent, global, } \\
\text { big, world-wide, north, Europe, constraint }\end{array}$ & $\begin{array}{l}\text { Throughout the } \\
\text { conference; } \\
\text { section: finances }\end{array}$ \\
\hline $\begin{array}{l}\text { Class } 3 \text { : description of } \\
\text { negotiations }\end{array}$ & $\begin{array}{l}\text { Conference, Bali, December, climate, } \\
\text { negotiation, protocol, American, European, } \\
\text { progressive, final, Friday, number, } \\
\text { Ministry, secretary, text, to ratify, to refuse, } \\
\text { Indonesia, Kyoto, united, Saturday }\end{array}$ & $\begin{array}{l}\text { End of the } \\
\text { conference }\end{array}$ \\
\hline
\end{tabular}

The auxiliary verbs (such as 'to be' and 'to have') indicate the past tense, pointing to the presence of temporal relationships. Significantly, present words relate directly to the conference and its objectives: Bali, December, negotiation, climate and costs. The names of all central actors of the conference also appear in class 3: UN secretary, ministers, scientists, delegates and delegation. Here the Bali conference events are evoked in a seemingly neutral manner using significantly few adjectives and adverbs but brute facts: 'Just after taking his oath, the new Australian prime minister ratified the Kyoto protocol' (Le Monde [LM], 5/12).

Class 1 of the French corpus is fairly close to class 3 of the German corpus. It is the second largest with $26.93 \%$ of the entire corpus analysed and contains vocabulary relative to finances, to transfer of technologies and to deforestation. Words specific to the topics climate change and relevant risks are present, such as degradation, flooding and drought. Again, we find verbs such as to help. In this context, technology and money appear as ways to cope with risks in poor countries: 'developing countries request the creation of adaptation funds which will help them prevent the consequences of climate change' (LM, 11/12).

Class 2 is the smallest of the corpus and concerns categories of words that specifically contain a large number of places and countries and their corresponding descriptions of greenhouse gas rates. This class particularly references developing countries, such as China and India, with whom other countries need to cooperate to reduce greenhouse gases on a large scale. The presence of a certain number of words that relate to the financial sector can also be noted, such as rival, consumption, product, competitive, finances, taxes, costs and growth. In addition, this class is more representative than the others of the financial section of the newspapers. Therefore, it is a matter of describing the financial stakes related to greenhouse gases reduction in the different countries: 'Another problem is that, without an international constraining authority, everyone is hoping that someone else will strive to reduce the emissions' (Libération [Li], 10/12).

Concluding, the press in France reports on two types of dynamics related to the Bali conference: political stakes (negotiations) on the one hand and financial stakes on the other. The latter allows for a distinction between risks for poor countries (flooding, 
drought) and risks for rich countries (competition, consumption). Therefore, as could be read in Le Figaro, 'if, for the rich, adaptation signifies building houses that float, for the poor it means learning to swim' (12/12).

\section{France/Germany comparison}

Beyond the differences in the number of classes, we observe that the French and German presses do not apprehend the Bali conference in the same way. The central themes evoked are very different: in France, the political and financial stakes of the Bali conference are presented by distinguishing the rich countries from the poor. Although political stakes are also identified in Germany (classes 1 and $2=35.11 \%$ ), this part of the corpus plays a smaller role than in the French corpus (class $3=55.83 \%$ ). The human component related to climate change is another dynamic, the largest class in the corpus, which is strongly present in the German one (in which poor countries represent one specific context). Similarly, in Germany, the financial stakes are uniquely present when poor countries are the subject of discussion. This financial dimension is thus presented solely as a solution and not as a preventative reason for rich countries to reduce their greenhouse gases, as is the case in France. However, the importance of class 4 'a problem for all of humanity' seems to indicate that the source of the climate problem is in our lifestyle, as in the source of the problem is human. Besides, the German press alternates its discourse between local perspectives (pointing to daily problems, a political agenda) and global perspectives (our lifestyles, the reduction of greenhouse gases), which is not the case in France.

Finally, we observe the role that risk plays in the two countries. In France, risk is exclusively associated with poor countries whereas in Germany, risk also appears in class 4, that is, the ensemble of humanity, indicating a greater proximity of risks. For example, in three daily papers (SZ, DW and FAZ, 12/12), Germany is placed on a scale of risks (Germanwatch climate risk index): 'In the climate risk index of 2008, for which the last 10 years where taken into account, Germany surprisingly attained position no. 10' (Frankfurter Rundschau [FR], 12/12).

\section{Metaphors in France and in Germany}

Table 4 provides a glimpse of the different metaphors observed which, as previously pointed out, only represents those which allow us to point to a process of objectification and anchoring according to the criteria defined by Wagner et al. (1995).

Final conference negotiations are described like a true psychodrama (Le Figaro [LF], 17/12), a soap opera, an emotional thriller (Li, 17/12) and a showdown (DW, 17/12; FAZ, 17/12). This rich vocabulary (also noticed in headings) reflects the emotions in the articles that recount the facts hour by hour, event by event. For example, a German article (DW, 17/12) describes a drama implying four characters: the friends of humankind (ONG) who provide courage to the gently powerful (Europeans) to fight the mean and all-powerful (USA) and the poor countries seeking justice. Also, the end of the conference is presented in the two corpuses like the end of a typical 'Hollywood-style film'. This metaphor renders the politicians ridiculous in their debates and the sequence of events becomes predictable. Therefore, the categories 'good' and 'bad' simultaneously anchor the conference debates and split the origin of the problem, a common way to deal with risk (Joffe, 1999). 
Table 4. Metaphors in German and French data

\begin{tabular}{|c|c|c|c|c|}
\hline $\begin{array}{l}\text { Source } \\
\text { domain }\end{array}$ & Target domain & $\begin{array}{l}\text { Period } \\
\text { covered }\end{array}$ & $\begin{array}{l}\text { Total } \\
\text { number of } \\
\text { articles }\end{array}$ & Some extracts \\
\hline $\begin{array}{l}\text { Hollywood } \\
\text { style film }\end{array}$ & $\begin{array}{l}\text { Description of final } \\
\text { negotiations }\end{array}$ & $\begin{array}{l}14 / 12, \\
17-18 / 12\end{array}$ & $\begin{array}{l}\text { France: } 4 \text {; } \\
\text { Germany: } 6\end{array}$ & $\begin{array}{l}\text { Showdown, soap opera, } \\
\text { an emotional thriller, } \\
\text { psychodrama }\end{array}$ \\
\hline War & $\begin{array}{l}\text { Description of tensions } \\
\text { between countries }\end{array}$ & $\begin{array}{l}3 / 12,5 / 12 \\
7 / 12 \\
11-17 / 12\end{array}$ & $\begin{array}{l}\text { France: } 18 ; \\
\text { Germany: } 2\end{array}$ & $\begin{array}{l}\text { Come to the frontline to } \\
\text { knock them (the USA) } \\
\text { down (regarding their refusal } \\
\text { to address their emission levels); } \\
\text { the French minister dropped a } \\
\text { bomb }\end{array}$ \\
\hline Religion & $\begin{array}{l}\text { Description of risk } \\
\text { and relationship } \\
\text { between countries }\end{array}$ & $\begin{array}{l}3-4 / 12 \\
7 / 12 \\
12-17 / 12\end{array}$ & $\begin{array}{l}\text { France: } 2 ; \\
\text { Germany: } 12\end{array}$ & $\begin{array}{l}\text { The prophets of the apocalypse, } \\
\text { the return of the prodigal son, } \\
\text { climate sins }\end{array}$ \\
\hline
\end{tabular}

Beyond this similarity, the daily newspapers in France and Germany use different metaphors to talk about the Bali conference. In France, the disaccord between Europe and USA becomes a descriptive combat as appears in the following words and expressions: go to the frontline to knock them down ( $\mathrm{Li}, 11 / 12)$, barrage, replace a good position (LM, 12/12) and battle (LM, 12/12; Li, 15/12; LF, 21/12...); when it comes to the subject of the USA, the newspaper Liberation wrote (14/12, our translation): 'the battle of Balithe United States versus Europe-in full swing. It was hushed. It was nonetheless head-on; each victim had a turn at 'bashing' and inflicting the Frenchies themselves when Paris refused the Iraqi obstacle.' This type of reference to past conflicts was observed multiple times. For example, Liberation speaks of the Berlin wall of climate (17/12), and Al Gore's remarks referencing the Second World War were published on 14/12 in both the German (DW) and French newspapers (LF), albeit differently by the two countries. Although French media reported on Mr Gore's discourse about postwar reparation, drawing a parallel with the Marshall Plan, German media highlighted the parallel he drew between the lack of environmental action with the one of the West against Hitler, pointing to a moral component to silence.

In Germany, many religious metaphors were observed by the presence of terms such as climate sins (SZ, 8/12; FR, 15/12), repentance (SZ, 4/12), prophets of the end of the world (FAZ, 17/12) and confession (SZ, 17/12). Some daily papers even outlined their narration of the facts with excerpts from the Bible, such was the case in the description of the Australian minister who ratified the Kyoto protocol as the parable of the prodigal child (SZ, 4/12). Furthermore, the protestant community even expressed themselves in the press (DW, 4/12) by articulating their commitment for the just reduction of greenhouse gases within a Creationist framework. If the moral dimension is strong in the German corpus, not all daily papers agree on this aspect. However, the debate takes place on this moral dimension. It is interesting to note that when the French press evokes Germany (LM, 7/12), metaphors of the crusades appear as a compromise between war and religion.

In summary, the objectification of the conference is salient in the French press through the use of the war metaphors, whereas in the German press it is through religious metaphors. These metaphors and the objectification that result from them allow us to assume 
that the climate negotiations in France are anchored in political-financial categories derived from relationships between countries, whereas in Germany they are anchored in moral categories.

\section{DISCUSSION}

In Germany, the pragmatic analysis shows that the conference is anchored in political and human categories, linking both local and global perspectives. On the semantic level, we have pointed out the use of religious metaphors that contribute to the moral anchoring of the climate question. The triangulation of these methods additionally sheds light on the various results: anchoring in the political and human categories is coupled by a moral dimension. The double reading of global and local levels shows that Germany is preoccupied both imminently and remotely by the moral and human aspects of climate change. Political dynamics are the lens through which human and moral stakes are examined. By shifting from global to local, the problems of other people become our problems, and moral categories are used to make sense of this dynamic. Also, the German press discourse brings an alter into play that resembles us, an alter ego. These results echo the history of the green movements in Germany in which different local groups are united around common ethical questions.

Furthermore, in France, the pragmatic aspects of the discourse shows that the Bali conference was anchored in financial and political categories, allowing for distinction between the rich and the poor, both in terms of solutions and consequences of climate change. Similarly, the war metaphors show objectification in a combative mode of opposition between countries. Also in France, the alter that is drawn from these results takes the form of an alter that is different from us in that it is poor countries, or political opponents, that will suffer more significantly. This financial and political reading of the Bali conference echoes the formation and structure of the French green movement around political matters following May 1968. Nonetheless, the reference to scientific knowledge, another route adopted by the green movements, is almost completely absent from the French media.

Also, by grasping SRs through both theoretical perspectives on discourse, we were able to propose more precise interpretations. For example, in Germany, the religious metaphors shed light on the human and political categories, which emerged in the pragmatic analysis. Therefore, triangulation appears as a way of improving the analysis.

In the same way, international comparison underlines that religious metaphors are quite absent in France, whereas in Germany war metaphors are rare. The comparison allows to highlight and to make a sense of 'absences' (Gervais, Morant \& Penn, 1999): the different historical evolution of green movements in both countries, the fact that France is a secular state or that Germany has a particular relationship to the Second World War, and so forth. Although it may never be possible to give a definitive interpretation of absences, comparison and triangulation give some indications and are a way of coping with absences rather than ignoring them.

Finally, results point to a greater proximity to risk in Germany, with global/local perspectives articulated in a dialogical manner. In France, the nature of risk varies according to the economic status (poor or rich country). However, there is currently no research that allows for clarification of the relationship to social and physical proximity of risk as well as perceived risk (Gattig \& Hendrickx, 2007). Moreover, we know that the probability of being affected by climate change is not the only factor used in evaluating 
risk and that emotional factors need to be taken into account (Joffe \& Lee, 2004; Böhm \& Pfister, 2005). We cannot therefore conclude that perceived risk is higher in Germany because proximity is greater. Nonetheless, French and German newspapers do not grant the same space to the discourse on risk.

Further limitations to our results ought to be mentioned. The analysis of metaphors, for example, is only one method among others to apprehend semantic aspects of discourse. Different analytical tools would surely enhance our results. Finally, we underline that this article does not aim to be an exhaustive description of the SRs of the Bali conference nor on climate change. Instead, the objective was to show, through the lens of the approach used, how two countries report differently on one single event.

Indeed, our results reveal the effect of the sociocultural context on the way in which the same event related to climate change and risk is represented by media in two different countries, highlighting some practical questions. Although France and Germany are two key European countries that play a decisive role in climate negotiation, the Bali conference is not represented by them in the same way. If in Germany, the question of morality is raised; the question in France is more political and financial. This result brings us to further investigate environmental questions in social psychology by taking the sociocultural context into account because it appears that environmental problems represent different objects depending on the context.

Furthermore, faced with risks that are denounced by scientists, climate conferences seek to establish a consensus as a way to meet the given challenges. Our results therefore bring us to further examine the way in which consensus can be drawn between countries that are often even more different than France and Germany. The metaphor of the Hollywood-style film and the process of splitting echoed by such a metaphor could constitute a form of consensus that nonetheless creates the risk that each country would be fixed into their various roles. In this context, an international comparison that takes the temporal dimension into account might prove useful to verify whether or not the SRs of the different countries evolve towards a consensus during consecutive climate conferences.

\section{REFERENCES}

Bauer, M. (2005). Distinguishing red and green biotechnology: cultivation effects of the elite press. International Journal of Public Opinion Research, 17, 63-89.

Böhm, G., \& Pfister, H.-R. (2005). Consequences, morality, and time in environmental risk evaluation. Journal of Risk Research, 8, 461-479.

Bonaiuto, M. Breakwell, G., \& Cano, I. (1996). Identity processes and environmental threat: the effects of nationalism and local identity upon perception of beach pollution. Journal of Community and Applied Social Psychology, 6, 157-175.

Caillaud, S. (2009). Utiliser la narration pour saisir les représentations sociales. Les Français et les Allemands face à l'écologie.Tr@jectoire, 3. http://trajectoires.revues.org/index286.html

Castro, P. (2006). Applying social psychology to the study of environmental concern and environmental worldviews: contributions from the social representations approach. Journal of Community and Applied Social Psychology, 16, 247-266.

Castro, P., \& Gomes, I. (2005). Genetically modified organisms in the portuguese press: thematization and anchoring. Journal for the Theory of Social Behaviour, 35, 1-18.

Castro, P., \& Lima, M. L. (2001). Old and new ideas about the environment and science. An exploratory study. Environment and Behavior, 33, 400-423.

Chibret, R.-P. (1991). Les associations écologiques en France et en Allemagne. Une analyse culturelle de la mobilisation collective. Thèse de doctorat soutenue le 01/02/1991. Paris I. 
Eder, K. (2000). L'environnement et le discours écologique: le cas de l'Allemagne. In M. Abélés, L. Charles, \& H.-P. Jeudy (Eds), L'environnement en perspective (pp. 191-208). Paris: L'Harmattan.

Ferry, L. (1992). Le nouvel ordre écologique. L'arbre, l'animal et l'homme. Paris: Bernard Grasset.

Flick, U. (1992). Triangulation revisited: strategy of validation or alternative? Journal for the Theory of Social Behaviour, 22, 175-197.

Flick, U. (1995). Social representations. An introduction into the theory and its implications for alternative views of psychology. In J.-A. Smith, R. Harré, \& L.-V Langenhove (Eds.), Rethinking psychology (pp. 70-96). London: Sage publications.

Foster, J. (2006). Media presentation of the mental health ill and representations of mental health problems. Journal of Community and Applied Social Psychology, 16, 285-300.

Gamson, W., \& Modigliani, A. (1989). Media discourse and public opinion on nuclear power: a constructionist approach. The American Journal of Sociology, 95, 1-37.

Gattig, A., \& Hendrickx, L. (2007). Judgmental discounting and environmental risk perception: dimensional similarities, domain differences, and implications for sustainability. Journal of Social Issues, 63, 21-39.

Gervais, M.-C. (1997). Social representations of nature. The case of the braer oil spill in Shetland. $\mathrm{PhD}$ in philosophy, London School of economics and political science, University of London.

Gervais, M.-C., Morant, N., \& Penn, G. (1999). Making sense of «absence»: towards a typology of absence in social representations theory and research. Journal for the Theory of Social Behaviour, $29,419-444$.

Haas, V., \& Jodelet, D. (1999). Pensée et mémoire sociale. In J. P. Pétard (Ed), Psychologie sociale (pp. 111-140). Paris: Edition Bréal.

Hansen, A. (1991). The media and the social construction of the environment. Media, Culture and Society, 13, 443-458.

Jacquiot, P. (2007). Comparaison des processus de formation et de diffusion du mouvement écologiste en RFA et en France. Cahiers Internationaux de Sociologie, 73, 217-244.

Jacquiot, P. (2008). Mémoire collective du nazisme et engagement écologiste en ex-RFA. Nouvelle Revue de Psychosociologie, 5, 169-181.

Jodelet, D. (2008). Social representations: the beautiful invention. Journal for the Theory of Social Behaviour, 38, 411-430.

Joffe, H. (1999). Risk and the "other”. Cambridge: Cambridge University Press.

Joffe, H. (2003). Risk: from perception to social representation. British Journal of Social Psychology, $42,55-73$.

Joffe, H., \& Haarhoff, G. (2002). Representations of flar-flung illnesses: the case of ebola in Britain. Social Science \& Medicine, 54, 955-969.

Joffe, H., \& Lee, L. (2004). Social representation of a food risk: the Hong Kong avian bird flu epidemic. Journal of Health Psychology, 9, 517-533.

Kalampalikis, N. (2003). L'approche de la méthode Alceste dans l'analyse des représentations sociales. In J.-C. Abric (Ed.), Méthodes d'études des représentations sociales (pp. 147-163). Paris: Editions Erès.

Kalampalikis, N., \& Haas, V. (2008). More than a theory: a new map of social thought. Journal for the Theory of Social Behaviour, 38, 449-459.

Kalampalikis, N., \& Moscovici, S. (2005). Une approche pragmatique de l'analyse Alceste. Cahiers Internationaux de Psychologie Sociale, 66, 15-24.

Keller, R. (1998). Müll—die gesellschaftliche Konstruktion des Wertvollen. Die öffentliche Diskussion über Abfall in Deutschland und in Frankreich. Opladen: Westdeutscher Verlag.

Kronberger, N., \& Wagner, W. (2003). Keywords in context: statistical analysis of text features. In M. Bauer, \& G. Gaskell(Eds.), Qualitative researching with text image and sound. A practical handbook (pp. 299-317). London: Sage Publications.

Lahlou, S. (1996). A method to extract social representations from linguistic corpora. Japanese Journal of Experimental Social Psychology, 35, 278-291.

Lahlou, S. (2001). Functional aspects of social representations. In K. Deaux \& G. Philogene (Eds.), Representations of the social (pp. 131-146). Oxford: Blackwell.

Licata, L., \& Klein, O. (2002). Does European citizenship breed xenophobia? European identification as a predictor of intolerance towards immigrants. Journal of Community and Applied Social Psychology, 12, 323-337. 
Marková, I. (2000). Amédée or how to get ride of it: Social representations from a dialogical perspective. Culture and Psychology, 6, 419-460.

Marková, I. (2003). Dialogicality and social representation. The dynamics of mind. Cambridge: Cambridge University Press.

Moscovici, S. (1994). Social representations and pragmatic communication. Social Science Information, 33, 163-177.

Moscovici, S. (2001). Why a theory of social representations? In K. Deaux, \& G. Philogène (Eds.), Representation of the Social (pp. 8-36). Oxford: Blackwell Publishers.

Ollitrault, S. (2001). Les écologistes français, des experts en action. Revue Française de Sciences Politiques, 51, 105-130.

Pragglejaz, G. (2007). MIP: a method for identifying metaphorically used word in discourse. Metaphor and Symbol, 22, 1-39.

Rudolf, F. (1998). L'environnement une construction sociale. Pratiques et discours sur l'environnement en France et en Allemagne. Strasbourg: Presses Universitaires de Strasbourg.

Wagner, W. (1994). Fields of research and socio-genesis of social representations: a discussion of criteria and diagnostics. Social Science Information, 33, 199-228.

Wagner, W. (1998). Social representations and beyond: brute facts, symbolic coping and domesticated worlds. Culture and Psychology, 4, 297-329.

Wagner, W., Elejabarrieta, F., \& Lahnsteiner, I. (1995). How the sperm dominates the ovum. Objectification by metaphor in the social representation of conception. European Journal of Social Psychology, 25, 671-688. 